\title{
Water security and national water law in Mexico
}

\author{
Úrsula Oswald Spring
}

\begin{abstract}
Background: This article develop analyses water security in Mexico, a country where global environmental change requires social, political and economic actors to protect natural resources and ecosystem services in order to reduce the tension between anthropogenic demands and natural availability. The paper asks: How can overexploitation and inequality in the access and control of water be assessed using an integrated model of water management and how could the existing water resources in each river basin and aquifer be sustainably distributed by a new National Water Law that would encourage participation in order to overcome the conflicts over access to and control of water?

Methods: With a model of integrated water management the article reviews the current use of water among different social and production sectors.

Results: Agriculture still consumes 77 per cent of the water, especially in the arid north, an area greatly affected by climate change (CC). Industry uses ten per cent and domestic users thirteen per cent of water. The growing megacities are also overexploiting their aquifers, producing subsidence and water pollution together with changes in land use, thus reducing water infiltration into the aquifers during the monsoon. Regional and temporal water stress is further aggravated by unsustainable production processes, where mining and agribusiness hog the water needed by indigenous people and small farmers, forcing them to migrate to the urban centres or illegally to the US.

Conclusions: Within this arena of conflict in the field of water management, the article offers several guidelines for a sustainable and participative National Water Law. Food security, including dignified life conditions for the small-scale farmers in rain-fed regions affected by CC, could be achieved with small scale irrigation system in the Southeast of Mexico, where water is available for a second crop. Their sustainable agriculture and preventive management of water pollution by organic agriculture are central activity for conserving and restoring the natural condition of water infiltration. Without an integrated water management, reduction of soil erosion, early warning and resilience-building among the exposed people, Mexico will not reduce the existing and future threats related to global environmental change and particularly to CC.
\end{abstract}

Keywords: Water management; Water security; National water law; Ecosystem services; Water conflicts; Equity; Sustainability

\section{Background}

The world population tripled during the last century, but water use grew six-fold during the same period. There is also worldwide concern over food production since today almost a billion people go hungry and in 2050 at least nine billion people will have to be fed. Population growth occurs primarily in the least developed countries in Africa and Asia. In this global context Mexico is considered a threshold country, where water use is that of a developing

Correspondence: uoswald@gmail.com

Úrsula Oswald Spring, Regional Centre for Multidisciplinary Research at the National Autonomous University of Mexico, Cuernavaca, Mexico country still highly concentrated in the agricultural sector. Mexico is located in the north of Latin America and to the south of the US with a $3,000 \mathrm{~km}$ border and the greatest socio-economic differences between two neighbouring countries. Mexico is also well known for its social, economic and environmental contrasts, with most of its territory in drylands but also with tropical perennial forests and marine and mountain ecosystems where the Nearctic and Neotropical ecosystems overlap.

In Mexico, high levels of poverty and inequality coexist with high rates of growth in selected sectors (multinational banks, TV, tourism) and an intensive exploitation of raw materials (oil, minerals and gas). Due to its fecund

\section{它}


nature and diverse ecosystems Mexico is the fourth most biodiverse country on earth (Groombridge \& Jenkin 2002). Large areas of land are controlled by agribusiness, with a high concentration of land and water resources (Garatuza Payán et al. 2011). Further, chaotic urbanization (Montero Contreras et al. 2009; Sobrino 2011), corrupt privatization processes and unsustainable development practices in tourism and mining have produced one of the most unequal societies, where economic growth is highly concentrated. The Gini index analysis this differences and shows that Chile (0.50) and Mexico (0.48) have the highest income inequality and the lowest educational performance among the countries belonging to the Organisation for Economic Co-operation and Development (OECD), and this has exacerbated tensions between social groups and classes. In Mexico 77.8 per cent of the population lives in urban areas and 53.8 per cent in metropolitan areas (Figure 1) (Sobrino 2011), where most of the domestic water is consumed and which have very low levels of sewage provision and recycling. Furthermore, most of the water is consumed by agriculture (Arreguín Cortés et al. 2010), especially by export agribusiness (Rangel Medina et al. 2011) in the arid regions of the north. In this context of environmental deterioration, overuse of water for irrigation, chaotic urbanization processes and unequal appropriation of national wealth, struggles over access to water (Perló \& González Reynoso 2009) and to control its supply have aggravated tensions and social inconformity (Oswald Spring 2005; Barkin 2011).

The article first analyses water security in Mexico using an integrated model of water management, where global environmental change $(\mathrm{GEC})^{\mathrm{a}}$ requires that social, political and economic actors protect the natural resources and ecosystem services (ESS) in order to reduce the tensions between anthropogenic supply and demand and natural availability (Oswald Spring 2011). After introducing the guiding research question, the next section develops an integrated model of water management. This methodological tool is used to analyse the current use of water by the different social and production sectors. The agricultural sector and growing cities are threatening water security by overexploiting their aquifers (Morales Novelo \& Rodríguez Tapia 2011), producing subsidence and water pollution together with land-use change. This unsustainable management is reducing the ESS and especially water infiltration into the aquifers during the monsoon season. The rainy season and arid conditions impose regional and temporal limits on water access in Mexico. But it is precisely in those arid regions with little water that most people live, the main irrigation districts and industrial zones are located, and the national wealth is produced. Access to water is further aggravated by unsustainable modernization and production processes, where mining and agribusiness are hogging the water needed by indigenous people and small farmers, forcing them to migrate to urban centres or illegally to the US. Furthermore, the global efficiency in the irrigation districts is barely approaching $40 \%$ and the inefficient urban water management at the local level increases scarcity and lowers water quality (Domínguez et al. 2011). In this context of contradictions, in 2011 access to water was included in the Mexican Constitution as a basic human right, and a new National Water Law (NWL) needs to be adopted to grant this basic human right to the most vulnerable people. In the Conclusion,

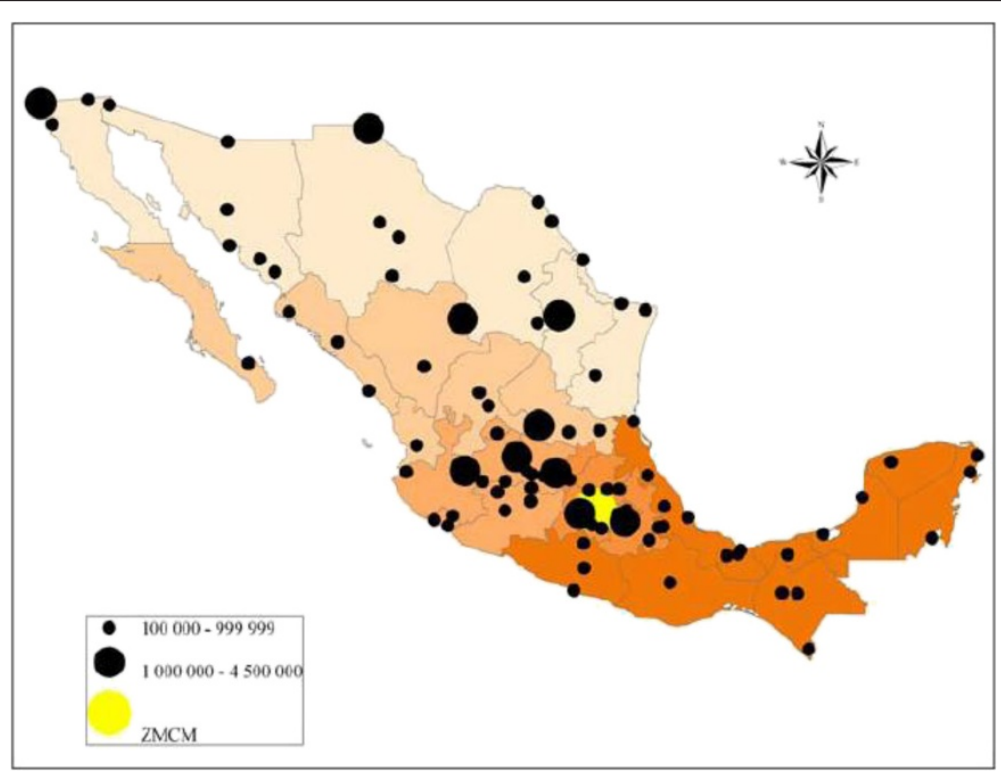

Figure 1 Principal urban distribution of population in Mexico. Source: [Sobrino 2011:9]. 
several ideas for a sustainable and participate National Water Law are proposed.

\section{Research questions}

This article analyses the following research question: (1) How can overexploitation and inequality in the access and control of water resources be assessed by an integrated model? and (2) How could existing water resources in each river basin and aquifer be distributed through a new participative NWL to bring about a sustainable management of scarce water resources by overcoming present conflicts over access to and control of water and offering even the most vulnerable groups enough water for life with dignity and sustainable production activities?

\section{Conceptual and methodological platform Concepts}

Water security refers to complex interrelations between people, human activities, energy, ESS, natural requirements for maintaining biodiversity, climate change (CC), and new demands related to hygienic living conditions, the alleviation of poverty, and socio-economic aspirations. In 2000 the Ministerial Declaration of the World Water Forum (Ministerial Declaration of The Hague 2000) proposed to grant every human being their basic needs (societal security), a safe, permanent and nutritious food supply (food security), and a livelihood (human security), and to protect ecosystems (environmental security), manage risks (HUGE security) (Oswald Spring 2009a), share and govern water resources (political security), provide basic public health (health security), and to value water (economic security) (Oswald Spring \& Brauch 2009a). Water security in Mexico cannot simply be achieved in quantitative terms; there must also be quality and a permanent service. In 2008, 604 treatment plants existed, and they produced $87,310 \mathrm{~L} / \mathrm{sec}$ of drinking water, using only 66 per cent of the installed capacity (Conagua 2008). But leaking pipes lose almost 40 per cent of the treated water, thus preventing permanent access to safe water (Declaración de Dublin 1992). The 'tandem' system (where water is distributed for a limited number of hours per day or days per week on a rota basis operated by the municipality) also reduces the water quality by changing the pressure within the conduits, and this allows microorganisms to penetrate the leaking pipes.

\section{Methods}

In methodological terms, this article uses an integrated model of water management to explore the linkages between the effects of GEC at the national, regional and local levels (Figure 2). It explores how consistent examinations of local environmental impacts and global economic pressure can be simultaneously addressed by taking into account all the supply factors in dynamic interrelations with the changing water demand. Only a transdisciplinary approach can link up rainfall, evaporation, soil, biodiversity, evapotranspiration and wetlands with surface water, recycled water and desalinated water and with the demand from agriculture, livestock, industry, service and domestic requirements, taking into account the alleviation of poverty, new hygienic conditions, and production processes. GEC and CC are also changing the existing conditions of water supply and demand.

\section{Results}

Greater demand for water and less availability in a generally dry country where production processes are concentrated in arid regions, together with GEC and CC, serve to intensify existing conflicts over water. In this struggle the most vulnerable are losing their traditional rights to water use, especially the indigenous and small-scale farmers in rain-fed regions, that is, in the recharge areas for surface and groundwater. But CC also presents new health threats, and the overexploitation of aquifers in big cities is causing more minerals such as arsenic and fluoride to be dissolved in the groundwater, and this particularly affects children and older people. In addition, administrative inefficiency, lack of political negotiation to reach agreements on water disputes, a rudimentary economic and tax system for water, lack of technological innovation in water-saving systems, counter-productive subsidies for electricity and diesel for the extraction of groundwater for agribusiness, and unsustainable management of the natural supply conditions make the integrated approach very complex. The scheme includes different types of positive and negative feedback, all of them related to the capacity of key social players to agree on a sustainable model of water management able to provide water in the long-term to all social groups and for necessary production processes, but reducing the overexploitation of natural and human resources.

As well as the various social and environmental causes, such as pollution, change in land-use, air contamination, urban growth, social inequity, an unsustainable model of development and the loss of the crucial ESS, Mexico is a very diverse country in environmental, production, cultural and social terms, with different indigenous and food traditions, and so there is a need for very different methods to conserve, administer and distribute water amongst its regions, sectors and people.

Furthermore, CC affects the tropics more seriously than elsewhere, and Mexico is especially exposed due to its long coasts located between two oceans, with warmer temperatures and more extreme events like drought, cyclones, floods and falling levels of precipitation creating new security risks for people, for livelihoods, for the environment (Oswald Spring \& Brauch 2009b), and for the infrastructure (Brauch et al. 2008, 2009, 2011). The high probability of an intensification of natural disasters, with more frequent and longer droughts, especially in the drylands 


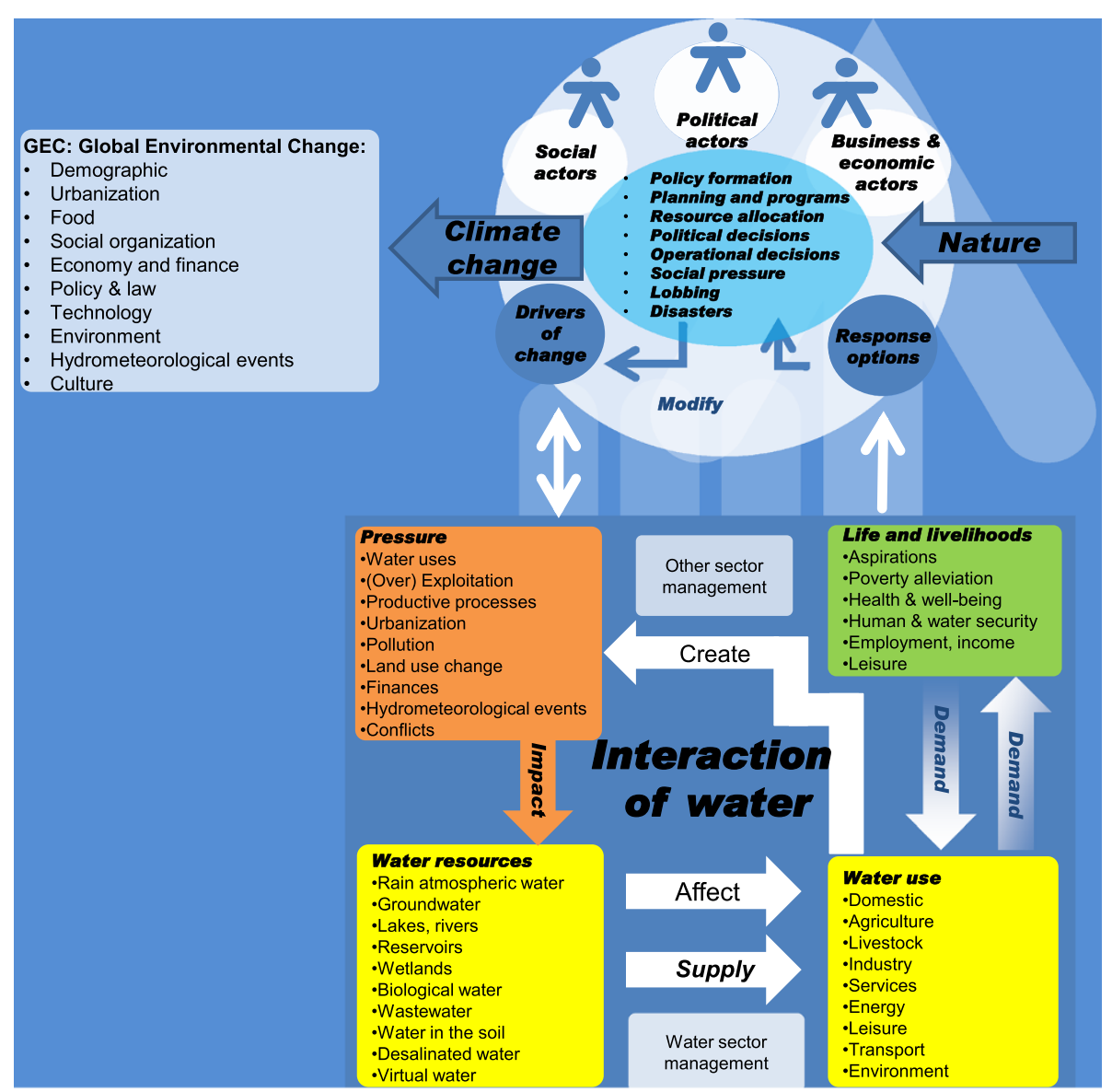

Figure 2 Integrated model of water management. Source: Adapted by the author from GWP [Global Water Partnership 2009]: 4.

(IPCC 2012), is already impacting irrigation agriculture in the north, access to clean and safe water in Mexico City, and also ESS and human health. Rising sea level will displace people and production activities (agriculture, livestock, petrochemicals and sugar cane factories, etc.) along the coasts, creating additional pressure on food security for Mexico (Oswald Spring 2009b).

Given the present and especially the future challenges for water management, this integrated model, which includes the negative feedback from CC, GEC, urbanization, population growth and the changing demands of social groups and of regions, explains why the an integrated management is highly complex. An increasing struggle over access to and control $^{\mathrm{b}}$ of water is forcing the authorities at the three levels of government (national, state, municipality), as well as organized society and the business community, to negotiate the changing conditions of water supply and demand by creating a new legal framework with different mechanisms of reinforcement, where water is considered a basic human right for everybody. Using this integrated model of analysis, the next section examines water management in different regions and sectors in Mexico.

\section{Analyses of water security in Mexico using an integrated model of water management}

The pressure on the surface, ground, soil, biological water and wetlands is linked to the three basic water consumers: agriculture (77 per cent), domestic services (13 per cent) and industry (10 per cent). But improvements in the quality of life, the aspirations of young people to overcome existing poverty, new types of employment, production processes, health and well-being all require more water. However, changes in land-use, the destruction of forests and jungles, and population growth are reducing the water supply, and higher temperatures with greater variability in rainfall are limiting access to water, especially in the drylands, where climate uncertainty is more evident. In Mexico there is a great imbalance between water availability, population settlements and production needs: 77 per cent of the people live in those areas that produce 87 per cent of Mexico's GDP but where only 31 per cent of the water is available. On the other hand, where 69 per cent of Mexico's water resources exist, 23 per cent of the population lives, and they produce 13 per cent of the national wealth, mostly in precarious socio-economic 
conditions and in extreme poverty, due to lack of governmental investment in irrigation facilities and development (Figure 3).

For these reasons, great tensions exist regarding water security, and this is further threatened by mining activities and by a lack of legal enforcement. Most of the urban areas are provided with tap water of unsafe quality. Mexico is one of the countries with the highest use of bottled water, especially following the cholera crisis in the early nineties (Barkin 2011). In rural areas, where about 24 per cent of the population lives, water supplies are officially available to 76.8 per cent of the population, but most of the communities suffer from the lack of a permanent water supply. Many communities collect their water during the rainy season or buy it from water tanks. In the urban area officially 94.3 per cent of the population have access to tap water, but the water supply is usually temporary (by daily or weekly 'tandem', see above) and people store their water in tanks or reservoirs (Conagua 2008). The differences between wealthy areas and marginal ones is reflected in their water supply, e.g. Ixtapalapa, a poor suburban area of Mexico City receives less than ten litres per person per day, often only once a week, while Lomas, a wealthy community in the capital, has unlimited access to water (Conagua 2012).

Nevertheless, the water supply in the capital city is becoming critical ${ }^{\mathrm{c}}$. The aquifers are overused, e.g. the Texcoco aquifer, in the eastern part of the Valley of Mexico, is the most overexploited aquifer on earth, with 850 per cent of over-extraction; this has resulted in subsidence affecting buildings and public infrastructure (Oswald Spring 2011), including the international airport. A 52-km tunnel is under construction which will be used to pump rain and sewage water out of the Mexico City valley, instead of allowing rain and treated sewage water to infiltrate the aquifers. This sewage water is pumped through an open channel to the Mezquital valley in the state of Hidalgo, where the biggest sewage treatment plant in Latin America is under construction; it is to be used for the irrigation of fresh vegetables (Cortes Muñoz \& Calderón Mólgora 2011). This water could have been treated in smaller plants within the city and reused in parks, gardens and industrial facilities, thus reducing extraction from the aquifer. With water harvesting techniques and treated sewage water from the suburban area (Chalco, Netzahualcoayotl, and other cities in the state of Hidalgo) the Mezquital Valley could produce an amount of vegetables equal to the demand from the Metropolitan Valley of Mexico City (MVMC).

Consequently, water availability is not only a problem of access but basically a problem of management. Furthermore, water use by agriculture is still high for a threshold country, with very low levels of efficiency and limited water-saving practices (Figure 4). Chihuahua pumps water from the Palaeolithic aquifer, while Sonora, Sinaloa and Tamaulipas obtain their water by gravity from rivers, dams and reservoirs (Palacios Vélez \& Mejía Saez 2011). Other important water users are Michoacán with surface water and Guanajuato with groundwater pumped from deep wells of more than $500 \mathrm{~m}$, which introduced brackish water into the agricultural land.

Often irrigation and urban water management both lack an integrated approach and they do not take into account the availability of water determined by environmental conditions, but are focussed on short-term personal economic

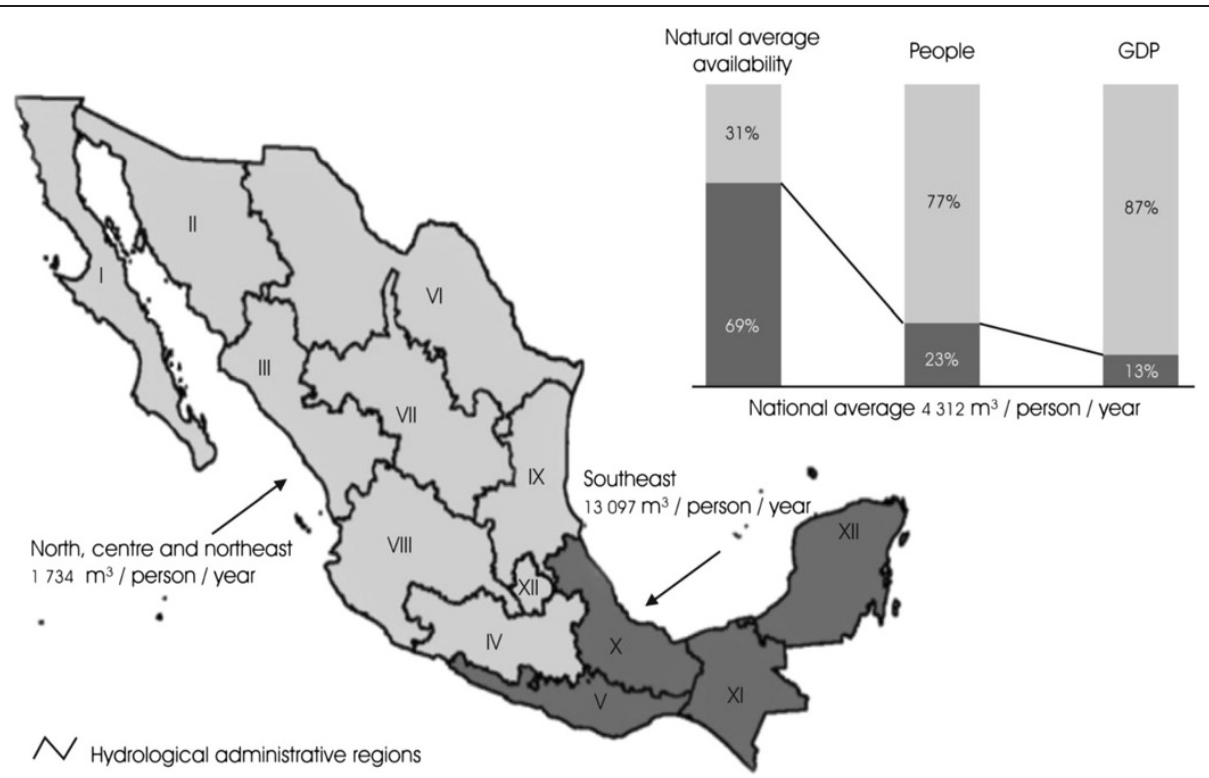

Figure 3 Regional contrast in terms of development and water availability. Source: [Arreguín Cortés et al. 2010]. 


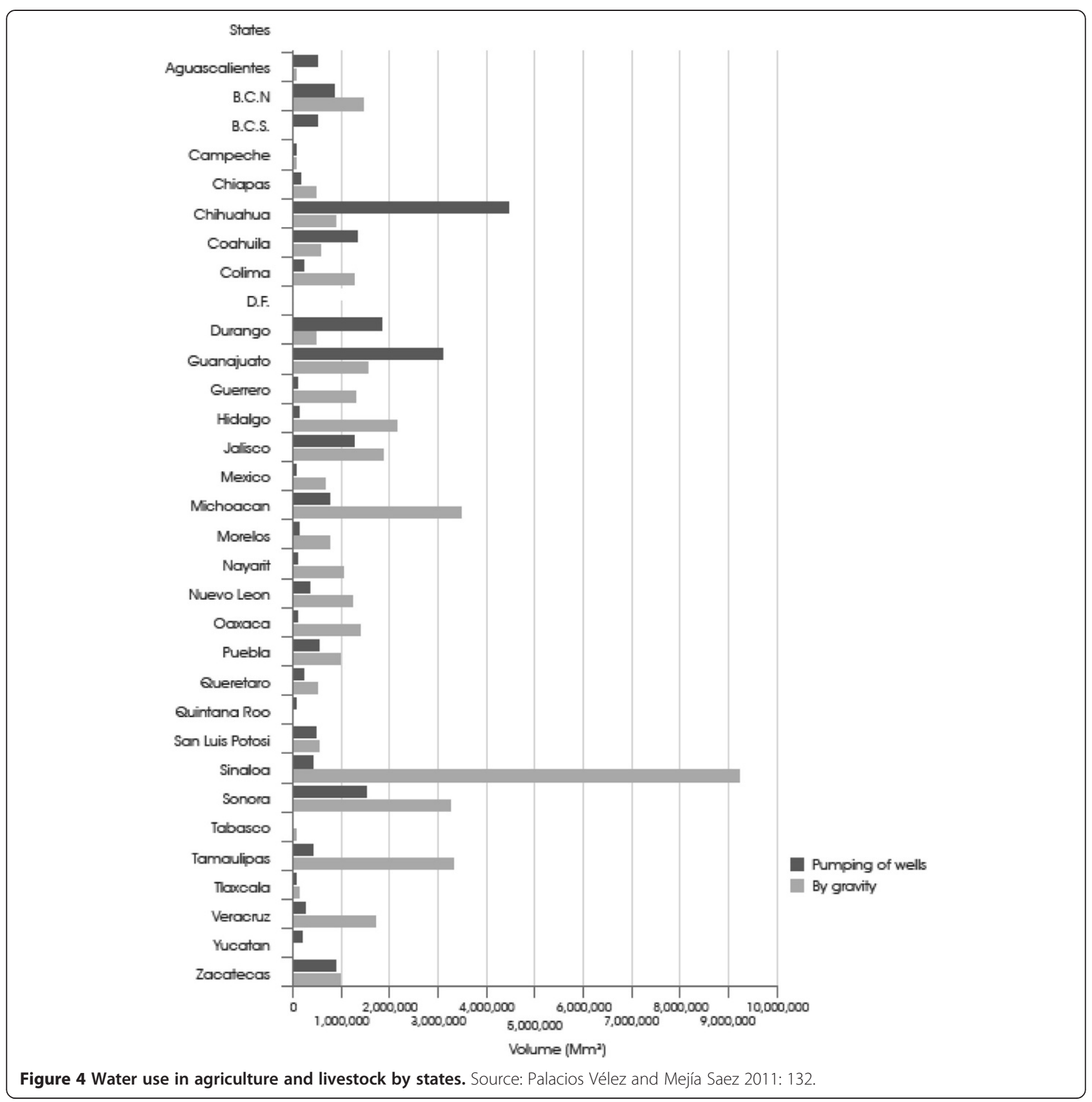

interests. An integrated approach (Figure 2) will include basin management, aquifer infiltration, rational water use, and sewage facilities, where the future of not only the MVMC but of the whole country is further under threat due to CC (Rosengaus 2007). Irrigation in the northern districts is also in a critical situation. None of the water users-urban-domestic, agricultural or industrial-take into account the amount and the regional and temporal availability of the water produced by ESS. All three key users require a permanent water supply, while the average precipitation is $775 \mathrm{~mm}$ or $1,488 \mathrm{~km}^{3}$ per year. The regional differences are important and there are zones in the north with less than $150 \mathrm{~mm}$, while some mountain areas in the south get over $5,000 \mathrm{~mm}$ of rainfall. Most of the monsoon rain occurs between June and September. This pattern of rain imposes not only regional but also temporal limits on availability and requires rigorous water, infrastructure and aquifer management. Average evapotranspiration and evaporation in Mexico is estimated about $1,084 \mathrm{~km}^{3}$, the run-off can reach $378 \mathrm{~km}^{3}$ and surface extraction is about $54 \mathrm{~km}^{3}$. The recharge of the aquifers (from the run off) is estimated at $79.6 \mathrm{~km}^{3}$, whilst at least $28.9 \mathrm{~km}^{3}$ are extracted for production processes and domestic uses (Conagua 2008, 2012). The water balance 
gets $34 \mathrm{~km}^{3}$ of imports from Guatemala and the US and exports $5.9 \mathrm{~km}^{3}$ mainly to the northern neighbour. This water balance varies depending on the monsoon and the values are estimated. During dryer periods less water is assigned to agriculture. Global water conditions are adequate for Mexico, but the regional and temporal distribution of water in Mexico is not related to the demands of a growing population and their production needs, and so it does not match water availability.

A permanent water supply during the whole year depends fundamentally on extraction from the aquifers; most domestic water is pumped out from groundwater. Figure 5 shows the overexploitation of the aquifers in the northern and central parts of the country, where the population is concentrated, production processes take place, and the arid climate means that a high amount of water is required for agribusiness. The overuse of groundwater, especially in the agricultural districts of Sonora and Baja California (northern border with the US) has also caused the intrusion of sea water into the aquifers (Figure 6). The most seriously affected states are Baja California Norte (BCN), Baja California Sur (BCS), Sonora, Coahuila and Durango. In this northern state, the overexploitation of the aquifer is fundamentally related to intensive water use for export agriculture and dairy production (see also Figure 4). After the North American Free Trade Agreement (NAFTA, 1994), several multinational enterprises have also transferred their production processes to Mexico, taking advantage of the cheap labour force in their neighbouring country and geographical proximity to important consumer centres in the south of the US (San Francisco, Los Angeles, Houston, etc.). Besides the natural fertility rate, a high level of immigration to the agricultural, industrial and newly-created service sectors has significantly increased water demand. The coasts of Veracruz and Coatzacoalco are also seriously affected by sea water intrusion; Coatzacoalco is an important centre for petrochemical production in Mexico and an intensive user of water in the industrial sector. The low-lying peninsula of Yucatán has also recently been affected by sea water intrusion (Pacheco Avila et al. 2011) and does not have surface rivers.

Not only are there problems of water quality related to sea water intrusion, but severe conflicts have also emerged in relation to seepage and sea water intrusion in $\mathrm{BCN}$ and Sonora, which are both arid and hyper-arid regions. The All-American Canal, a $130 \mathrm{~km}$-long aqueduct located in south-eastern California, has replaced the Alamo Canal, which was located mostly in Mexico. The new AllAmerican Canal is built with impermeable materials and represents the only water source for the Imperial Valley in California. With the Alamo Canal, ninety per cent of the seepage entered Mexico and the local authorities and business communities built a system of pumps and drainage to avoid widespread flooding and to recover the seepage. With the new 37-km canal, completed in 2009, the water was rerouted to the Imperial Valley irrigation district, preventing seepage into Mexico. The Mexicali business community from $\mathrm{BCN}$, civic organizations, and two California environmental NGOs sued the project in a US federal court. They argued that it violated the water rights of Mexican water users and violated US environmental statues because of the seepage's effects on the nearby Andrade Mesa wetlands. But there is no worldwide agreement on the management of shared aquifers and seepage. The new canal's construction, carried out without consultation with Mexico, might not be understood as a sign of

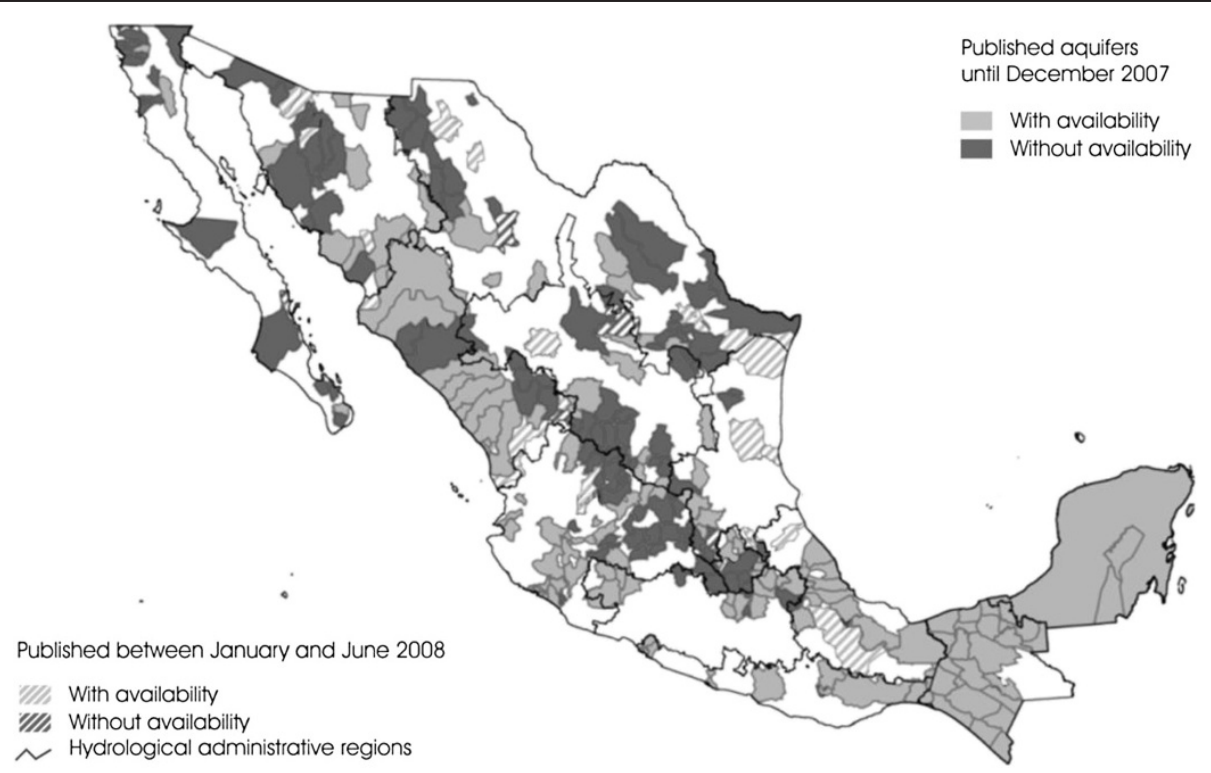

Figure 5 Availability of groundwater. Source: Conagua, 2008. 


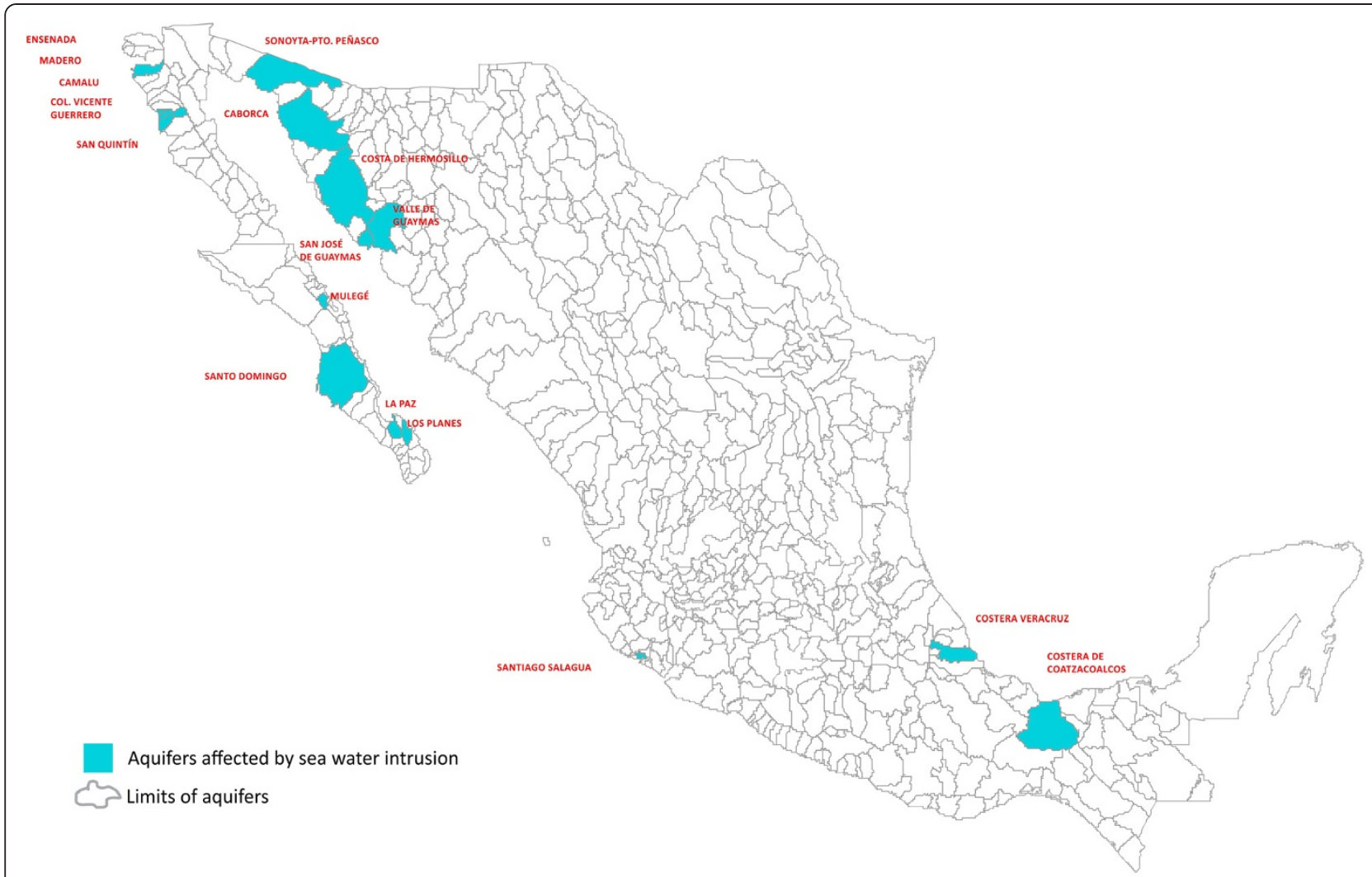

Figure 6 Sea water intrusion in Mexico. Source: Conagua 2008.

friendly relations between neighbours. The canal's construction and the absence of seepage have seriously affected the economic activities of $\mathrm{BCN}$ and there are now several projects for constructing an aqueduct to supply the Mexicali valley with water. Nevertheless, any aqueduct takes away water from another region, affecting its water users, and creating new conflicts, as has happened in Sonora.

To mitigate the intrusion of salty water almost $25 \mathrm{~km}$ (Rangel Medina et al. 2011) into the aquifer of the Hermosillo valley (Sonora; Figure 7) and the negative water balance for the city of Hermosillo, the Mexican government has built an aqueduct from the Novillo dam, without consulting the indigenous Yaquí people and without taking into account their traditional water rights. Extraction of the water began in early May 2013, even though state and local governments were not granted permission to transfer the water by the National Water Commission. Indigenous groups blocked the international highway 15 from Mexico to Nogales for several weeks near the community of Vicam. The Supreme Court ruled in July 2013, after months of blockage of the highway, that the indigenous people were the legal owners of the water rights and that the state government had preceded without taking their water rights into consideration. Now the Ministry of the Environment (Semarnat) is required to study the environmental impact and state and local governments must negotiate a resolution to the existing water conflict by peaceful means.

But it is not only water scarcity, overexploitation of the aquifers and intrusion of sea water that are affecting the availability of safe water in Mexico. Safe drinking or potable water from the tap must be free from damaging organisms such as bacteria, viruses, protozoa (unicellular eukaryotic organisms) and helminths (nematode worms). Safe water should be free from inorganic (arsenic, fluoride, lead, nitrates, nitrites, asbestos) and organic toxic substances (VOC: volatile organic compounds such as the hydrocarbons benzene and toluene, chloroform used in producing drinking water, bisphenol from plastic containers and coatings; siloxanes from personal care products such as deodorants; brominated organics for fireretardant clothes, etc.), also called emergent pollutants (Cortes Muñoz and Calderón Mólgora 2011). But drinking water must also be aesthetically acceptable: without flavour, odour or colour, transparent and free from total dissolved solids and turbidity. Water quality is permanently monitored by Conagua (Figure 8 (Conagua, 2008)).

Water quality is greatly affected by population concentration and industrial activities, which are concentrated in Mexico around the capital and the metropolitan valley of Mexico City, Guadalajara (Lerma-Santiago River), Monterrey, the northern Gulf and petrochemical 


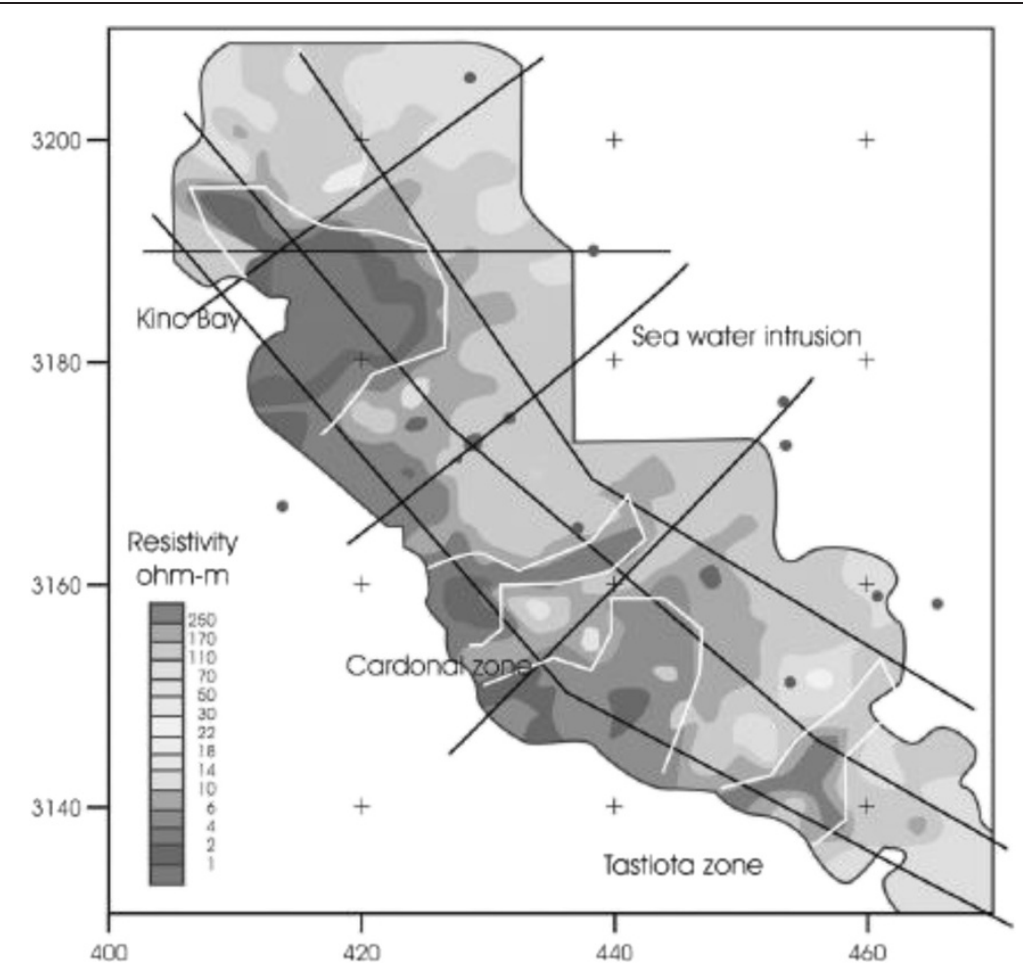

Figure 7 Sea water intrusion into the aquifer in Sonora. Source: Rangel et al. 2011: 83.

production in the Central Gulf region. Total suspended solids as an additional indicator of biochemical demand of oxygen (BOD) particularly affects coastal zones in the Pacific from Colima to Guerrero, the south of Veracruz and Tabasco on the Atlantic, and also the rivers of Santiago-Lerma, Bravo and Soto La Marina. In general, in the mountains and in isolated areas with low population density water quality is excellent. But as soon as urban and production processes begin, water quality is affected, as was the case $18 \mathrm{~km}$ from a mountain source in Tlaxcala with the river Atoyac (Oswald Spring 2005).

There are two generic national standards (NOM-001SEMARNAT-1996 and NOM-002-SEMARNAT-1997) which address the reduction of water pollution in Mexico. These standards apply to those users who generate localized discharges into federal waters and land receptors. Hence discharges from industries and municipal water are controlled by these two standards, while agriculture, which is not only the biggest consumer but also the most important polluter because of its diffuse discharges (with the exception of pig and dairy farms), is not controlled. Pesticides are excluded from taxes, and in agriculture electricity and diesel are subsidized, thus encouraging agribusiness to expand further into drylands and to extract water from already overexploited aquifers.

In a case study in Guanajuato (in the centre of Mexico and its former breadbasket), (Pérez Espejo and Pérez Espejo 2011) found that in the national drinking water the maximum limits had been exceeded by heptachlor epoxide, lindane, and methoxychlor. All these pesticides are restricted or they are prohibited in Mexico. She also detected triazines and carbamates, for which there are still no standards in Mexico. But insufficient legal enforcement and the absence of laboratories means there is no control of these toxins. This diffuse pollution in agriculture exists in many parts of the world, while there is little awareness of the environmental impacts of pesticides because of a low level of education, especially among farmers who believe that more chemicals and fertilizers will increase their harvest.

Water quality is therefore threatened by diffuse pollution from agriculture, by a lack of municipal sewage plants or by inadequately managed ones, and by highly toxic industrial sewage from sugar cane factories, food and beverage processors, petrochemical and agrochemical plants, and mining and steel activities. Finally, in Mexico water quality and availability is also threatened by climate change (CC) (Semarnat-INECC 2012).

\section{Impacts of climate change}

Going back to the integrated water model (Figure 2), the pressure on water resources and the overexploitation of regional water reserves in drylands, basically due to the irrigation of cash crops and to population growth, means that water supply is further under pressure from GEC $\left(\right.$ see footnote $\left.{ }^{\mathrm{a}}\right)$. All these factors mean that the Mexican 


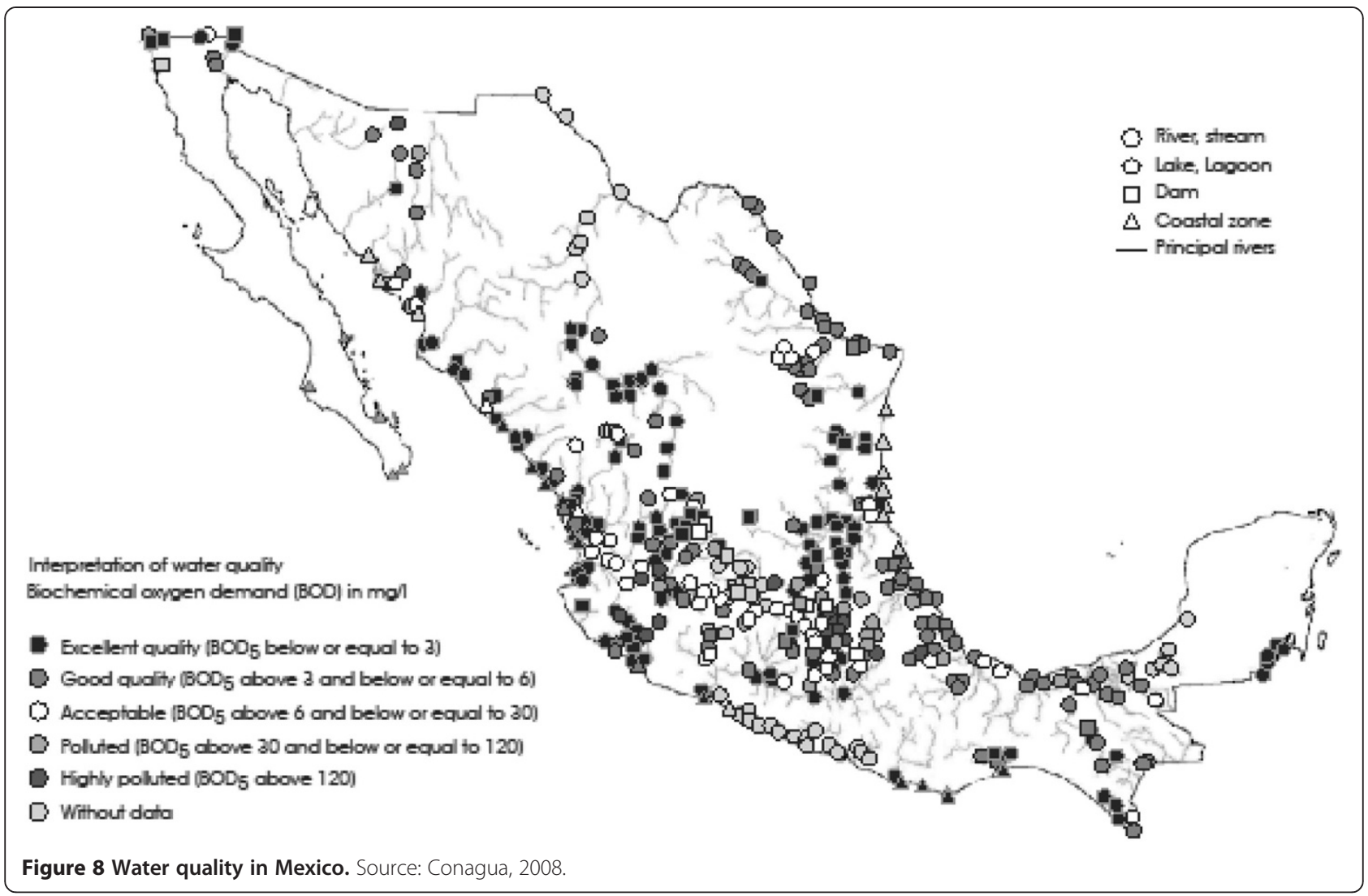

government must regionally and productively restructure the allocation of water, taking into account existing natural water reserves in time and space and including the projections of CC impacts. Hydrometeorological impacts are estimated to affect 68 per cent of the population which produces 71 per cent of the GDP. A rise in sea level of $60 \mathrm{~cm}$ during this century may put an additional 3.2 million people along the coasts in danger, especially in Tabasco, where 21 per cent of the territory is threatened, while in Quintana Roo, with the most important tourist facilities, 81 per cent of the land may be affected. According to projections for 2050, if the increase in temperature is stabilized at $2^{\circ} \mathrm{C}$ above pre-industrial levels, the estimated biodiversity loss is still 40 per cent (SemarnatINECC 2012).

These CC impacts create further threats for an integrated water management in Mexico. The three megacities of the MVMC, Guadalajara and Monterrey are all located in semi-arid regions and have limited water resources. Furthermore, new drivers of CC mean that the authorities need to better understand and manage the water cycle. They must plan the natural infiltration zones for their cities, restore the surrounding natural areas, improve sewage facilities for disposing of solid and liquid waste in the cities, and reduce the loss of almost 40 per cent of the water supply due to old and leaking pipes. All urban areas must also improve their poor water administration and compensate for the lack of water availability with technological improvements, water-saving measures (Domínguez et al., 2011), and better water education for all citizens.

Mexico is situated between two oceans, the Pacific and the Atlantic, and has more than $11,000 \mathrm{~km}$ of coastal areas. Most of them are exposed to cyclones, tropical storms, droughts, sea level rise and intrusion of sea water into the aquifers, especially those which are currently overexploited will soon be affected. Furthermore, the lack of environmental planning and the change in land use from forestry to agriculture and later to urban areas is substantially reducing the capture and infiltration of water into the aquifers, lakes, dams, rivers and reservoirs. But the reduction and loss of permanent and seasonal ice, combined with more intense and frequent heatwaves, aggravated by changes in the traditional rainfall patterns, and by more severe and more frequent storms with flash floods, all affect the availability of surface water and groundwater. More frequent and more severe disasters have taken people with low levels of adaptation by surprise, and the most vulnerable have again lost almost all their belongings (mountain areas of Chiapas, Oaxaca and Guerrero). But more extreme events have also destroyed the ground cover in the mountain regions. Hurricane Stan 
destroyed forty per cent of the forest cover of the southern Sierra Madre, and ninety-two rivers changed their courses in Chiapas, producing a damage of US $\$ 2.2$ billion in the poorest state of Mexico. These fast-changing conditions represent new challenges for an integrated management of water, especially when uncertainty is high and the predictability of these extreme events is still at a low level.

In the drylands more severe and longer-lasting droughts are related to an alteration in global thermohaline circulation, where an excess of fresh water is now discharged into the oceans. There is also an increase in evapotranspiration and more water vapour in the low and high clouds are both changing existing climate patterns (Rosengaus 2007). All these on-going changes and projected new ones will aggravate existing water scarcity, where human mismanagement in urban and rural water administration again means that the people in the poorest regions will suffer. The population must cope not only with the existing lack of water infrastructure, but must also resolve new threats related to GEC (climate vulnerability, urbanization, population growth, social inequality, migration and others), where the most vulnerable are rain-fed small farmers who will lose their means of survival. ${ }^{\mathrm{d}}$ But their lack of a political voice or any means of exerting pressure are forcing them to leave their livelihoods due to the deteriorating conditions and to rebuild their precarious lives in urban areas or as undocumented migrants in the US. The impact of CC will not just be limited to water management; it affects the whole water cycle: pollution, scarcity, waterborne illnesses (dengue fever, malaria, diarrhoea) and changes in rainfall patterns, and more frequent and severe extreme events such as droughts, flash floods and cyclones. The best preventive behaviour is to restore the deteriorated ecosystem on the coast (mangroves), in the dry tropical forests, and in the mountain regions, to manage solid and liquid water, to reduce erosion, to carry out urban and environmental planning, to prepare people with resiliencebuilding from bottom-up for more severe and more frequent extreme events and to improve water management with reuse, recycling and rainwater harvesting.

\section{Discussion: Need for a new legal framework for water}

Mexico is confronted by multiple anthropogenic global environmental changes (Brauch et al. 2008, 2009, 2011), aggravated by the severe impact of CC. This situation obliges the country to address present and future developments with a multi-task planning, including attention to demographic and urbanization factors, food security, social organization, economics, investment, and a preventive response to disasters with environmental restoration. To fulfil these complex duties and at the same time to overcome existing water conflicts, and to avoid any new pollution and the mismanagement of water, there is a great need to draft a new National Water Law
(NWL). In October 2011 the Mexican Senate changed the Constitution and included water as a basic human right. Now both the Senate and the Chamber of Deputies must draft a new legal framework to protect also the human rights of the most vulnerable people in remote rural areas, who are mostly indigenous people and women left as heads of households due to the migration of their partners.

This NWL must overcome the tendency to manage water scarcity through the use of engineering tools (aqueducts, basin transfers, sewage plants, etc.). This approach increases the overexploitation, pollution and scarcity of water, especially in a country where legal enforcement and the use of regulatory instruments are weak and poor people neglected. Thus, an integrated approach for a participative NWL must include different relationships to nature, where ESS, water conservation, the ecology of coastal zones, erosion, air quality, the thermal and toxic effects of ocean discharges, oxygen levels, salinity, impacts on fishing and agriculture, tourism, rainfall harvesting and recharge of aquifers are among the new priorities. Agriculture is affected by CC, but it is also the most important polluter of water (Pérez Espejo and Pérez Espejo 2011) and there is neither a policy nor legal framework to control this contamination.

The framework for this new and legally binding instrument should basically protect and recover the crucial natural conditions of ESS and improve in the middle and long term the supply of freshwater resources. This means that the legal representatives need to start with a two-pronged approach: firstly, to resolve existing mismanagement e.g. in the urban centres and in the northern agribusiness districts, where water is too scarce and overexploited to continue with a business-as-usual policy. This means charging the real costs of the water use, including its management, sewage, reuse and recycling, and a new culture of saving and reduction of pollution. Secondly, a sustainable planning must reorient population growth, agriculture and production activities towards areas where water is naturally available, e.g. the south and south-east of Mexico-mostly poor and politically abandoned regions, but very rich in natural resources. The government should promote development processes and support also private investments in these regions. Based on the principles of sustainability, the new NWL must guide planning and investment for the future, avoiding the transfer of water from one basin to another, as occurs now in the MVMC and with intense conflict in Hermosillo, affecting natural resources and the production potential of local people in other basins. A sustainability principle also means that any development project and new investment must allow an integrated scientific water assessment, where the first priority is granting the human right of each citizen to clean and sufficient water for their personal consumption and survival. Other uses can later be publically debated by regional water committees, providing that they always take into account an integrated approach to water management, 
conservation and restoration of ESS. Mexico's new NWL should also be based on scientific assessments. Water tariffs should reflect all external costs and encourage the users to save water and reduce pollution.

A crucial theme for Mexico is its food production for present and future generations. In 2012 imports of grains such as maize amounted to 10.8 million tonnes, one million more than in 2011, whereas wheat rose from 4.3 to 6.1 million and soybeans from 3.8 to 4.4 million (Agricultural Market Advisory Group 2013). Urquía Nuria Fernandez (FAO representative in Mexico) estimated for the next ten years, based on projections by the US Department of Agriculture, an increase in maize imports of fifty per cent, reaching 17 million tonnes, in beef by 104 per cent $(542,000$ tonnes), and in chicken by seventy per cent (242,000 tonnes). Nonetheless, (Turrent Fernández et al. 2012) rejected these projections and, taking into account adverse climatic conditions and the impacts of $\mathrm{CC}$, they projected that Mexico could produce the necessary basic food by changing to an intensive agricultural model among small farmers in Oaxaca, Guerrero, Chiapas, Yucatán and Campeche. They proposed sustainable agricultural practices, improved management of water, agricultural extensionism and public investment, including the establishment of new irrigated land in these states ${ }^{\mathrm{e}}$. They argue that forty-three per cent of maize is produced today by rain-fed agriculture (Figure 9) and that more than half of this small-scale production operates with low efficiency and can be easily improved. Mexico can raise its maize production annually from 23 to 33 million tonnes over the next ten years using the same plots of land that are cultivated today with governmental support. This means that the present deficit of ten million tonnes per year would be eliminated. With additional irrigation systems in land used for extensive livestock in the south and south-east of Mexico, combined with integrated soil management (Brauch \& Oswald Spring 2011), these small farmers could add 24 million tonnes per year during a second cycle, enough to cover the growing demand for maize for the year 2025. This change in policy from importation to production of basic food in the most marginal region of Mexico would grant the country food security and food sovereignty (Oswald Spring 2011) in times of critical grain shortages at the global level. A policy of food promotion with credits, small-scale irrigation, extensionism and market facilities may also enhance regional development and could reduce the existing social injustice in these poorest southern regions.

Food scarcity and the sudden rise in food prices have created worldwide hunger riots and Mexico's people were the first to fight in January 2007 for subsidies to stabilize tortilla prices with the slogan "sin maiz no hay país" (without maize there is no country). The combination of water scarcity, CC, high food prices, bioenergy and lack of basic food items is a dangerous situation where environmental security is easily lost (Conca \& Dabelko 2002). In different countries, basic human necessities are being securitized in order to avoid failed states and civil wars; and public insecurity related to the drug war creates a complex process of social relationships in the country (Oswald Spring \& Brauch 2009b). A crucial item addressed by the proposed NWL is therefore food security, including dignified life conditions for the small-scale farmers in rain-fed regions affected by CC. As their land is basically in mountain regions, the paradigm of sustainable agriculture and preventive management of water pollution by organic agriculture is a central future activity for conserving and restoring the natural condition of water infiltration. This will also include some resettlement of people in regions threatened by flash floods, landslides and extreme droughts. Without an integrated water management, reduction of soil erosion, early warning and resilience-building among the exposed people, Mexico will not reduce the existing and future threats related to global environmental change and particularly to CC.

Finally, within this participative NWL, besides food security, the service and the industrial sectors, including tourism, must be protected. They are crucial areas of income and employment for a growing population with aspirations to overcome the high levels of poverty. In 2012, the industrial sector was responsible for 34.2 per cent, services for 61.7 per cent and agriculture for 4.1 per cent of the generation of GDP, while industry accounted for 24 per cent, services 58 per cent (tourism alone 8.3 per cent) and agriculture 18 per cent of Mexico's employment (INEGI 2013, 2010). All these factors must be taken into account in the new legal framework. This also means negotiating with the dominant business community, where almost eighty per cent of employment is generated within small and medium enterprises. Society must then create a counterbalance against the abusive practices of some (transnational) business sectors. This counterbalance should also support the government in promoting greater equity and justice in the existing unequal allocation of resources. During the next 15 years within the emerging new legal framework the prevailing water rights must be revised and the water must be reassessed in accordance with this law.

The new NWL should also be able to reorient activity towards sustainable development processes, so that Mexico can offer the 45.5 per cent of its population who are poor (56.3 million people) (Coneval 2013) dignified life conditions within the country and within their communities. It is precisely the promotion of food sovereignty in poor entities that will increase equity in social and regional terms.

New threats and disasters contribute to uncertainty and unpredictability with non-linear socio-natural outcomes, which increase global and personal risks (Beck 2011). The 


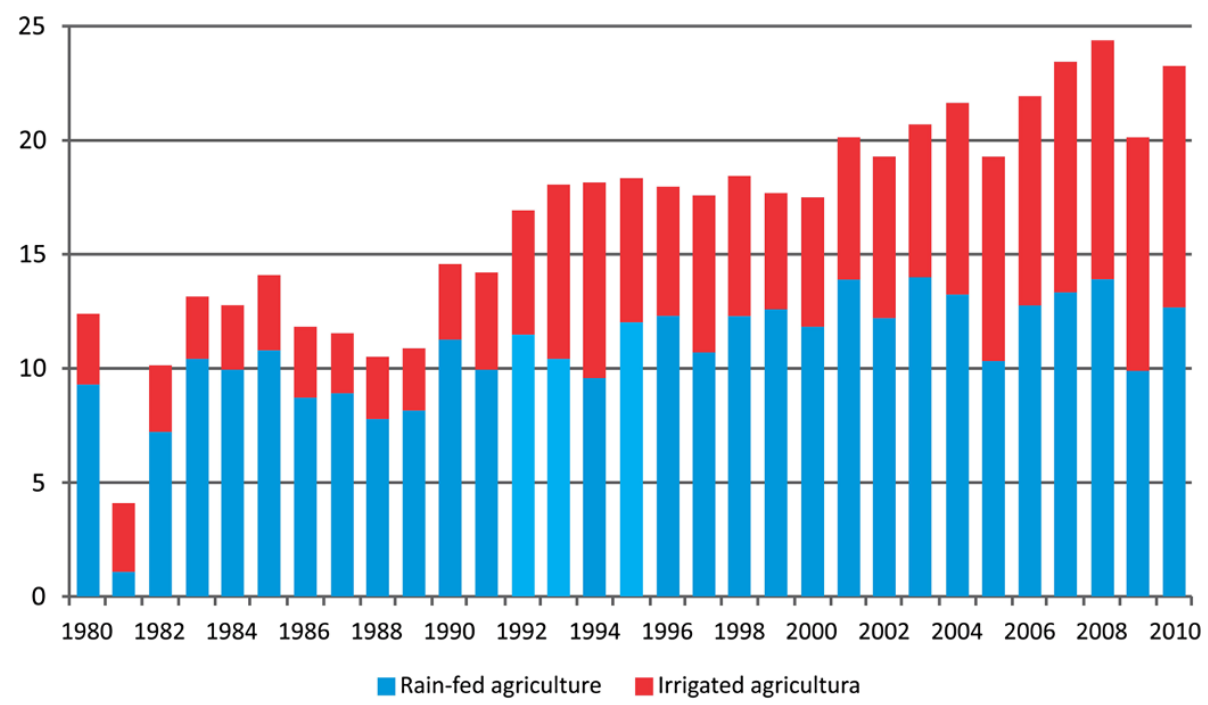

Figure 9 Rain-fed and irrigated maize production in Mexico. Source: SIAP, 2013.

social and environmental vulnerability (Villagrán de León 2006) of the most affected will substantially reduce their human security (CHS 2003). The geographical location of Mexico, between two oceans with a substantially warmer water temperature, and the alteration of the traditional monsoon pattern will bring the people more adverse conditions, as projected by the IPCC special report on extreme events (IPCC 2012, 2013). Consequently, an integrated water management in highly risky conditions also presents an obligation to promote adaptation processes in each region to reduce existing threats and to prevent new conditions of social and environmental vulnerability developing (IPCC 2012).

\section{Conclusions}

The goal of this article was to provide an analytical tool for an integrated diagnosis of water management in Mexico. The research questions were discussed in the context of a model of water management with nexus to soil, food and livelihood (Coneval 2013; Oswald Spring 2009a, 2009b, 2011). A new NWL in Mexico designed in the terms presented may allow the integration of the complex and often contradictory processes of Mexican water management. This NWL must also be able to negotiate conflicting interests within the new framework, where national, regional and local basin management prioritize water allocation as a basic human right and not as a business tool. On the other hand, the NWL must be able to reorganize existing unsustainable development processes, understand potential CC impacts, overcome existing poverty and reorient poor water administration so that it is able to improve food, human, gender and environmental security. These challenges require the involvement of all of society. Only through collective efforts will it be possible for all stakeholders to be involved in acting in a different legal framework, where factional interests must be controlled by the global interests of a society eager to achieve inclusive and sustainable development not only for itself but also for the coming generations. Water is the vital key element in the present and will be more important in the future. To achieve these multiple goals, only a truly participative and informed society will be successful, and only an integrated approach to water management will allow Mexico to deal with the ongoing threats of global environmental change.

\section{Endnotes}

${ }^{\mathrm{a}}$ Global environmental change (GEC) includes climate change (CC). It refers to the transformation produced by human being in the Ecosphere affecting the hydrosphere, atmosphere, biosphere, lithosphere and pedosphere. The alteration in the Anthroposphere are related to changes in the agricultural production, the urbanization, population growth, productive processes, transportation, emissions of greenhouse gases, land use changes, water pollution, deforestation and waste production.

${ }^{\mathrm{b}}$ Currently there are almost 400,000 land and water conflicts reported in Mexico, most of them related to the privatization process in local water administration systems, dams, aquifer construction without consulting the traditional water users, mining and other industrial pollution, sea water intrusion in aquifers, and overexploitation of aquifers resulting in the deterioration of water quality for the domestic user (Pacheco Avila et al. 2011).

${ }^{\mathrm{c}}$ Water withdrawal in the Metropolitan Zone of Mexico City (MVMC) is linked to population growth; in 1990 the growth rate in Mexico City was 1.64 per cent, but it declined to 0.86 per cent between 2000 and 2005 . 
Nevertheless, the growth rates of the surrounding states belonging to the MVMC are very high: Hidalgo 2.61, Tlaxcala 1.75 and Mexico 1.56 from 2000 to 2005. "Fourfifths of the demand is extracted from the Valley of Mexico Basin and the remaining fifth, amounting to a volume of $622 \mathrm{hm}^{3}$, is imported...In 2004, the total water withdrawal in the Valley of Mexico Basin was $1,943 \mathrm{hm}^{3}$, of which $241 \mathrm{hm}^{3}$ or 12 per cent was drawn from surface water and $1,702 \mathrm{hm}^{3}$ or 88 per cent from groundwater...the water to be imported for 2025 was projected to amount to $771 \mathrm{hm}^{3}$, and for 2030 it would be $830 \mathrm{hm}^{3}$...over-exploitation of the aquifers amounting to $751 \mathrm{hm}^{3}$ for the year 2004, the over-exploitation for 2025 is projected at $1,360 \mathrm{hm}^{3}$, and at $1,471 \mathrm{hm}^{3}$ for 2030 . Clearly, such a high water withdrawal is impossible." [Morales Novelo \& Rodríguez Tapia 2011: 402-403].

${ }^{\mathrm{d}}$ The projection for $\mathrm{CC}$ impacts on maize production is that between 13 and 27 per cent of the actual surface dedicated to maize may be lost, and this will generally affect the most vulnerable rain-fed peasants and subsistence farmers [Semarnat- INECC 2012 and SemarnatINECC 2013].

${ }^{\mathrm{e}}$ Mexico has 58 native species of maize, which produce the ingredients for 600 pluricultural food items. The technique of planting maize with fruit trees for small-scale farmers, developed by INIFAP and El Colegio de Posgraduados, the reduction of erosion and the infiltration of rainwater would increase carbon sequestration and the recharge of the aquifers.

\footnotetext{
Abbreviations

BCN: Baja California Norte; BCS: Baja California Sur; BDO: Biochemical demand oxygen; CC: Climate change; Conagua: Comisión Nacional del Agua; Conagua: National commission of water in Mexico; Coneval: Consejo Nacional de Evaluación de la Política de Desarrollo Social; ESS: Ecosystem services; FAO: Food and agriculture organization; GEC: Global environmental change; HUGE: Human, gender and environmental security; INECC: National institute of ecology and climate change in Mexico; INEGI: Instituto Nacional de Estadísticas y Geografía; MVMC: Metropolitan valley of Mexico city; NAFTA: NAFTA, North American Free Trade agreement; NGO: Nongovernmental organization; NWL: National water law; OECD: Organization for economic co-operation and development; RETAC: National scientific network on water research of the national council of science and technology; Semarnat: Ministry of environment and natural resources of Mexico; SIAP: Servicio de información agroalimentaria y pesquera; VOC: Volatile organic compound.
}

\section{Competing interests}

With this article I do not have any conflicting interests due that I am working at the National Autonomous University of Mexico in water research.

\footnotetext{
Acknowledgements

Part of this work was discussed collectively during the three national congresses of water and water management organized by the National Network on Water Research, Conacyt (RETAC, in Spanish). Ideas were further developed during the research project PAPIIT IN300213 of the National Autonomous University in Mexico entitled "Integrated water management of a river basin affected by climate change: risks, adaptation and resilience". Ideas about the National Water Law (NWL) were developed further during the third congress of RETAC through discussions among 450 water researchers, NGOs, social movements and public functionaries interested in developing a sustainable and equitable Water Law that respects water as a basic human right. Among these collective efforts, I am especially grateful to
}

Elena Burns, Nathalie Seguin and Raquel Gutiérrez for their hard work in the elaboration of the draft of the proposed NWL. I also thank Michael Headon the careful revision of the English, Hans Günter Brauch for the academic discussion and the anonymous peer reviewers for their critical inputs.

Responsible editor: Michael Piasecki

Received: 14 November 2013 Accepted: 24 January 2014 Published: 6 March 2014

\section{References}

Agricultural Market Advisory Group (2013) Agricultural commodities products. CME Group, Washington, D.C, http://www.cmegroup.com/trading/ agricultural/

Arreguín Cortés F, López Pérez M, Marengo Mogollón H (2010) Mexico's Water challenges for the 21st century. In: Oswald Spring Ú (ed) Water resources in Mexico: scarcity, degradation, stress, conflicts, management, and policy. Springer, Berlin, pp 21-39

Barkin D (2011) La ingobernabilidad en la gestión del agua urbana en México. In: Oswald Spring Ú (ed) Retos de la investigación del agua en México. CRIM-UNAM, CONACYT, Cuernavaca, pp 539-552

Beck U (2011) Living in and coping with world risk society. In: Brauch HG, Oswald Spring Ú, Mesjasz C, Grin J, Kameri-Mbote P, Chourou B, Birkmann J (eds) Coping with global environmental change, disasters and securitythreats, challenges, vulnerabilities and risks. Springer, Berlin, pp 11-16

Brauch HG, Oswald Spring Ú (2011) Securitizing the ground, grounding the security. Bonn, UNCCD

Brauch HG, Oswald Spring Ú, Mesjasz C, Grin J, Dunay P, Chadha Behera N, Chourou B, Kameri-Mbote P, Liotta PH (2008) Globalization and environmental challenges: reconceptualizing security in the $21^{\text {st }}$ century. Springer, Berlin

Brauch HG, Oswald Spring Ú, Grin J, Mesjasz C, Kameri-Mbote P, Chadha Behera N, Chourou B, Krummenacher H (2009) Facing global environmental change: environmental, human, energy, food, health and water security concepts. Springer, Berlin

Brauch HG, Oswald Spring Ú, Mesjasz C, Grin J, Kameri-Mbote P, Chourou B, Birkmann J (eds) (2011) Coping with global environmental change, disasters and security-threats, challenges, vulnerabilities and risks. Springer, Berlin

CHS (Commission on Human Security) (2003) Human Security Now, Protecting and empowering people. Commission on Human Security, New York

Conagua (2008) Programa Nacional Hídrico (PNH 2007-2012). Conagua and Presidencia de la Republica, Mexico

Conagua (2012) Atlas del agua en México 2012. Conagua, México, D.F

Conca K, Dabelko GD (2002) Environmental Peacemaking. John Hopkins University Press, Woodrow Wilson Center Press, Baltimore

Coneval (2013) Análisis y medición de la pobreza. Coneval, México, D.F

Cortes Muñoz JE, Calderón Mólgora CG (2011) Potable water use from aquifers connected to irrigation of residual water. In: Oswald Spring Ú (ed) Water resources in Mexico: scarcity, degradation, stress, conflicts, management, and policy. Springer, Berlin, pp 189-200

Declaración de Dublin (1992) Declaración de Dublín sobre el Agua y el Desarrollo Sostenible. http://www.wmo.int/pages/prog/hwrp/documents/ espanol/icwedecs.html

Garatuza Payán J, Rodríguez JC, Watts CJ (2011) Environmental monitoring and crop water demand. In: Oswald Spring Ú (ed) Water resources in Mexico: scarcity, degradation, stress, conflicts, management, and policy. Springer, Berlin, pp 101-110

Groombridge B, Jenkin MD (2002) World atlas of biodiversity. Nairobi, UNEP-WCMC, U. of California

GWP [Global Water Partnership] (2009) Towards water security: a framework for action. http://www.gwp.org/Global/ToolBox/References/Towards\%20water\% 20security.\%20A\%20framework\%20for\%20action.\%20Mobilising\%20political\% 20will\%20to\%20act\%20(GWP,\%202000).pdf

INEGI (2010) Datos estadísticos. INEGI, Aguascalientes, www.inegi.org.mx. INEGI. XIII Censo General de Población y Vivienda, 2010. Aguascalientes: INEGI; 2010

INEGI (2013) Datos estadísticos. INEGl, Aguascalientes, www.inegi.org.mx

IPCC (2012) Special Report on Extreme Events (SREX). IPCC, Geneva

IPCC (2013) WGI AR5. Summary for Policymakers. IPCC, Geneva

Domínguez AM, Ortiz VJB, Gutiérrez FVC, González, MAM, Yamanaka VHA, Silvestre JM, Rendón GAO, Mejía PC, Herrera AG, Soberanis MP, Lourdes Rivera Huerta M, Palacios LM, Romero CEM, Tzatchkov VG (2011) Assessment of a water utility agency: a multidisciplinary approach. In: Oswald Spring Ú (ed) Water resources in 
Mexico: scarcity, degradation, stress, conflicts, management, and policy. Springer, Berlin, pp 421-434

Ministerial Declaration of The Hague (2000) Water security. World Water Forum, The Hague

Montero Contreras D, Gómez Reyes E, Carrillo González G, Rodríguez Tapia L (2009) Innovación tecnológica, cultura y gestión del agua: Nuevos retos del agua en el Valle de México. D.F.: UAM, México

Morales Novelo J, Rodríguez Tapia L (2011) The growth of water demand in Mexico city and the over-exploitation of its aquifers. In: Oswald Spring Ú (ed) Water resources in Mexico: scarcity, degradation, stress, conflicts, management, and policy. Springer, Berlin, pp 395-406

Oswald Spring Ú (2005) El valor del agua: Una visión socioeconómica de un conflicto ambiental. Coltlax, Gobiernos del Estado de Tlaxcala, Fondo Mixto Conacyt, Tlaxcala

Oswald Spring Ú (2009a) A HUGE gender security approach: towards human, gender, and environmental security. In: Brauch HG, Oswald Spring Ú, Grin J, Mesjasz C, Kameri-Mbote P, Chadha Behera N, Chourou B, Krummenacher H (eds) Facing global environmental change: environmental, human, energy, food, health and water security concepts. Springer, Berlin, pp 1165-1190

Oswald Spring Ú (2009b) Food as a new human and livelihood security issue. In: Brauch HG, Oswald Spring Ú, Grin J, Mesjasz C, Kameri-Mbote P, Chadha Behera N, Chourou B, Krummenacher H (eds) Facing global environmental change: environmental, human, energy, food, health and water security concepts. Springer, Berlin, pp 471-500

Oswald Spring Ú (2011a) Aquatic systems and water security in the Metropolitan valley of Mexico city. Curr Opin Environ Sustain 3:497-505

Oswald Spring Ú (2011b) Seguridad del agua, conflictos e hidrodiplomacia. In: Oswald Spring Ú (ed) Retos de la investigación del agua en México. CRIM-UNAM, CONACYT, Cuernavaca, pp 441-454

Oswald Spring Ú, Brauch HG (2009a) Securitizing water. In: Brauch HG, Oswald Spring Ú, Grin J, Mesjasz C, Kameri-Mbote P, Chadha Behera N, Chourou B, Krummenacher $\mathrm{H}$ (eds) Facing global environmental change: environmental, human, energy, food, health and water security concepts. Springer, Berlin, pp 175-202

Oswald Spring Ú, Brauch HG (eds) (2009b) Reconceptualizar la seguridad en el siglo XXI. CRIM,CCA,CEIICH-UNAM, Senado de la República, Cuernavaca

Pacheco Ávila J, Cabera Sabsires A, Barcelo Quintal M, Alcocer Can L, Pacheco Perera M (2011) Environmental study on cadmium in groundwater in Yucatan. In: Oswald Spring Ú (ed) Water resources in Mexico: scarcity, degradation, stress, conflicts, management, and policy. Springer, Berlin, pp 239-250

Palacios Vélez E, Mejía Saez E (2011) Water use for agriculture in Mexico. In: Oswald Spring Ú (ed) Water resources in Mexico: scarcity, degradation, stress, conflicts, management, and policy. Springer, Berlin, pp 129-141

Pérez Espejo R (2011) Contaminación del agua por la agricultura: Retos de política. In: Oswald Spring Ú (ed) Retos de la investigación del agua en México. CRIM-UNAM, CONACYT, Cuernavaca, pp 605-616

Perló CM, González Reynoso A (2009) ¿Guerra por el Agua en el Valle de México? UNAM/PUEC, México D.F

Rangel Medina M, Monreal Saavedra R, Watts C (2011) Coastal aquifers of Sonora: hydrogeological analysis maintaining a sustainable equilibrium. In: Oswald Spring Ú (ed) Water resources in Mexico: scarcity, degradation, stress, conflicts, management, and policy. Springer, Berlin, pp 73-65

Rosengaus M (2007) Informe Interno: procedimientos para estimar tendencias del análisis parcial de datos históricos, 40 años de datos diarios, Tmax, Tmin y precipitación, tendencias, promedio nacional, todos los meses y anuales de 1961 a 2000 a nivel nacional, regional y estatal. CSMN, México D.F

Semarnat- INECC (2012) Mexico: Quinta comunicación nacional ante la Convención Marco de las Naciones Unidas sobre el Cambio Climático. Semarnat-INECC, México D.F

SIAP (2013) Servicio de Información Agroalimentaria y Pesquera. SAGARPA, Mexico, www.siap.gob.mx

Sobrino J (2011) La urbanización en el México contemporáneo. CEPAL, Santiago de Chile

Turrent Fernández A, Wise TA, Garvey E (2012) Factibilidad de alcanzar el potencial productivo de maíz de México. Wilson Center, Washington, D.C, Report 24

Villagrán de León JC (2006) Vulnerability: a conceptual and methodological review. UNU-EHS, Bonn, Source 4

doi:10.1186/2194-6434-1-7

Cite this article as: Oswald Spring: Water security and national water law in Mexico. Earth Perspectives 2014 1:7.

\section{Submit your manuscript to a SpringerOpen ${ }^{\circ}$ journal and benefit from:}

- Convenient online submission

- Rigorous peer review

- Immediate publication on acceptance

- Open access: articles freely available online

- High visibility within the field

- Retaining the copyright to your article

Submit your next manuscript at $\gg$ springeropen.com 